\title{
Population structure and spread of the Polychaete Diopatra biscayensis along the French Atlantic Coast: Human-assisted transport by-passes larval dispersal
}

\author{
Sarah Ann Woodin ${ }^{a, *}$, David S. Wethey ${ }^{a}$, Stanislas F. Dubois ${ }^{b}$ \\ a Department of Biological Sciences, University of South Carolina, 715 Sumter Street, Columbia, South Carolina \\ 29208, USA \\ ${ }^{\mathrm{b}}$ IFREMER, DYNECO Laboratoire d'Ecologie Benthique, F-29280 Plouzané, France \\ *: Corresponding author : Sarah Ann Woodin, tel.: +1 8037774254 or 18037829727 ; \\ email address : woodin@biol.sc.edu \\ wethey@biol.sc.edu ; Stanislas.Dubois@ifremer.fr
}

\begin{abstract}
:
Intertidal populations of the ecosystem engineering polychaete, Diopatra biscayensis, were analyzed on the French Atlantic coast for three years with individual size estimated from tube-cap aperture. All but the northernmost population along the Bay of Biscay have yearly recruitment. Individuals live 3-5 years and are likely reproductive as one year olds. Simulations indicate dispersal distances are $<50$ km; yet, populations also exist within the Normano-Breton Gulf in the western English Channel, more than $450 \mathrm{~km}$ from the northernmost Bay of Biscay population at La Trinité-sur-Mer. Three of the four populations in the Normano-Breton Gulf have no young of the year, but are near to active mussel culture where mussel seed is transported on ropes from dense $D$. biscayensis areas in the VendéeCharente region in the Bay of Biscay. The majority of $D$. biscayensis were adjacent to the likely source, mussel seed ropes. Transport assisted by aquaculture is the likely explanation for the populations in the Normano-Breton Gulf.
\end{abstract}

\section{Highlights}

Bay of Biscay populations show yearly recruitment except in northernmost. $>$ recruitment in only one of four Normano-Breton Gulf populations. Normano-Breton Gulf populations stem from aquaculture-assisted transport. dispersal simulations used to estimate connectivity. populations have demographic storage effect and short distance dispersal.

Keywords : Diopatra biscayensis ; ecosystem engineer ; larval dispersal ; aquaculture ; life history ; human-assisted-transport ; connectivity 


\section{Introduction}

The polychaete genus Diopatra is well-known as an ecosystem engineer in marine sediments, affecting both sediment and community characteristics in a density dependent manner (BaileyBrock 1984; Luckenbach 1986; Myers 1972; Woodin 1978). From the perspective of its effects on the dynamics of sedimentary assemblages and their physical properties, the distribution and abundance of Diopatra is of significance (Berke et al. 2010). The range of Diopatra biscayensis has been expanding northward in the Bay of Biscay since the late 1960s (Glemarec 1979) and now ranges from Arcachon France $\left(44.6585^{\circ} \mathrm{N}, 1.1423^{\circ} \mathrm{W}\right)$ near the border with Spain to La Trinité-sur-Mer $\left(47.5830^{\circ} \mathrm{N}, 3.0242^{\circ} \mathrm{W}\right)$ in southern Brittany in France. Surprisingly, $D$. biscayensis then reappears in the English Channel at the head of the Normano-Breton Gulf, over $450 \mathrm{~km}$ from its last known location and has a final northern limit within the Bay of Mont-SaintMichel in France (Berke et al. 2010; Fauchald et al. 2012; Wethey and Woodin 2008; Wethey et al. 2011).

Wethey and Woodin (2008) and Wethey et al. (2011) built metapopulation models for Diopatra and Berke et al. (2010) used regression tree analysis and in all cases their models indicated that the distribution is limited by cool summer temperatures (SST $<18$ or $\left.18.8^{\circ} \mathrm{C}\right)$. Their models suggest that the thermal conditions of the distal half of the Brittany Peninsula are currently not permissive for Diopatra reproduction and thus prohibit expansion along the coast from the Bay of Biscay into the Normano-Breton Gulf. Their models also predicted that the entire Brittany 
peninsula would only become permissive in the late $21^{\text {st }}$ century, which would then allow expansion into the English Channel and north. Based on these analyses, it is very surprising that Diopatra has already colonized the Normano-Breton Gulf. Here we examine the distribution of Diopatra biscayensis, and make comparisons between the contiguous populations of the Bay of Biscay and the disjunct populations of the Normano-Breton Gulf, populations over $450 \mathrm{~km}$ beyond the end of the Bay of Biscay populations. The questions of interest are as follows: 1. are the population characteristics of these disjunct northern populations different from those of the French coast of the Bay of Biscay; 2. could planktonic larval dispersal be the source of these disjunct populations and if not, what other source is likely? To address these questions we (1) measured the density and size structure of eight populations in the Bay of Biscay from Arcachon to La Trinité-sur-Mer and those of the four populations in the Normano-Breton Gulf from 2011 to 2013 , (2) looked for spatial associations of Diopatra with aquaculture structures, and (3) ran larval dispersal simulations to address the connectivity of the populations within each region and across regions.

\section{Materials and Methods}

\subsection{Diopatra}

On the Atlantic coast of Europe there are at least five species of Diopatra that occur in shallow subtidal to intertidal waters (Berke et al. 2010; Fauchald et al. 2012; Pires et al. 2010; Rodrigues et al. 2009). South of Arcachon, France $\left(44.6585^{\circ} \mathrm{N}, 1.1423^{\circ} \mathrm{W}\right)$, D. neapolitana appears to predominate in most intertidal areas. However, the distribution of D. marocensis is expanding, is 
already common in parts of the Portuguese coast (Rodrigues et al. 2009), and is known to have been present in northern Spain from as early as 1976 (Arias et al. 2010). From Arcachon, France to La Trinité-sur-Mer $\left(47.5830^{\circ} \mathrm{N}, 3.0242^{\circ} \mathrm{W}\right)$, D. biscayensis is the predominant species in the intertidal (Berke et al. 2010), though D. neapolitana is still present in the intertidal at Arcachon (Pires et al. 2010) and in the subtidal further north (S. Dubois unpub.). Individuals in populations from the English Channel are morphologically identical to D. biscayensis and were used in the description of the species (Fauchald et al. 2012).

\subsection{Census}

Population densities were estimated from June to mid-July at some sites in 2010 and at more sites in each year in 2011, 2012, and 2013. At each census, densities of Diopatra were estimated from counts of $0.25 \mathrm{~m}^{2}$ quadrats taken every $5 \mathrm{~m}$ along a 50 to $100 \mathrm{~m}$ transect line parallel to shore within the Diopatra zone at that location. Diopatra are often continuous in their distribution, given appropriate habitat, and the transect approach works well in such locations (Woodin 1978). The sizes of the Diopatra zone vary with location. Generally individuals of Diopatra are found from the shelf break and below. In a location with a very shallow slope such as at Châtelaillon-Plage, the intertidal zone of occurrence might be several hundred meters wide. If large areas of inappropriate habitat such as reef or rock or mud slurries resulted in discrete patches of Diopatra, then total counts within a known area within the patch were used; typically all individuals were measured within $10 \times 10 \mathrm{~m}$ areas. 


$$
\text { Density }=\frac{N}{\pi \sum N N D^{2}}
$$

113 Total search area was estimated from the convex hull of the UTM coordinates. Population

Alternatively, if densities were so low that few quadrats contained any individuals so that most transects of $10 \mathrm{~m}$ or more would contain 1 or 0 individuals, densities were estimated from nearest neighbour distances (Diggle 1975) using Universal Transverse Mercator (UTM) coordinates of individuals. In such sparse populations transect data yields little information on distances between individuals. Given that reproduction for such species is a function of separation between adults, knowledge of inter-individual distances is important in assessing the viability of a population. With higher densities, transects yield this information when multiple individuals are found within $0.25 \mathrm{~m}^{2}$ quadrats. Coordinates were measured with a Garmin Foretrex 101 GPS (2010 to 2012) and with a Spectra Precision Mobile Mapper 10 (2013), both with real-time differential corrections. Mobile Mapper coordinates were postprocessed using data from nearby public reference stations to increase precision (std. error $\sim 0.5 \mathrm{~m}$ ). Population density was estimated from $\mathrm{N}$ individual nearest neighbour distances (NND) using the Diggle (1975) relationship for randomly dispersed individuals: densities were calculated using Eq. 1, and the $95 \%$ confidence limits were calculated from the nearest neighbour values using the Diggle (1975) estimate of the standard error of the reciprocal of density.

\subsection{Bouchot Census}

The original sites where Diopatra was first discovered within the Normano-Breton Gulf were near Sabellaria reefs with nearby bouchot mussel culture sites: Sainte-Anne reef near Cherrueix 
$121\left(48.6459^{\circ} \mathrm{N}, 1.6459^{\circ} \mathrm{W}\right)$ and reef near Champeaux $\left(48.7327^{\circ} \mathrm{N}, 1.5521^{\circ} \mathrm{W}\right)$. We surveyed

122 those areas as well as others associated with bouchot mussel culture alone: Quatre Vaux

$123\left(48.6065^{\circ} \mathrm{N}, 2.2235^{\circ} \mathrm{W}\right)$ in the Baie de l'Arguenon and Saint-Géran $\left(48.6467^{\circ} \mathrm{N}, 2.2966^{\circ} \mathrm{W}\right)$ in

124 the Baie de la Fresnaye and Jospinet $\left(48.5515^{\circ} \mathrm{N}, 2.6066^{\circ} \mathrm{W}\right)$ in the Baie de Saint-Brieuc. We

125 found that $D$. biscayensis at the Sabellaria reef sites were usually near the reefs, at the edges but

126 rarely within the reef. At mussel culture sites, there were extensive rows of bouchots, which are

127 vertical wooden pilings, $30 \mathrm{~cm}$ in diameter and $3 \mathrm{~m}$ high, typically separated by $\sim 1 \mathrm{~m}$ (Prou and

128 Goulletquer 2002). Bouchots are set up in parallel rows $100 \mathrm{~m}$ long, often in pairs of rows

129 separated by $\sim 5 \mathrm{~m}$ with the next set of bouchots $\sim 20 \mathrm{~m}$ away. Also at these sites were chantiers,

130 which are racks for the seed recruitment ropes. These racks hold rows of seed ropes parallel to

131 the sediment surface, approximately $1 \mathrm{~m}$ above the sediment. Chantiers are 3 to $5 \mathrm{~m}$ wide, and

132 are placed 1 to $3 \mathrm{~m}$ from each bouchot row in more sheltered (western) regions of bays. We

133 surveyed throughout the spaces between the bouchot rows, including areas adjacent to bouchots,

134 in the chantier areas, and in the $20 \mathrm{~m}$ wide open areas between the sets of bouchot/chantier rows.

\subsection{Size Measurements - Tube-Cap Aperture Diameter and Age Estimation}

137 Tube-cap aperture diameters were measured in the field by delicate insertion into the tube-cap

138 aperture of a brass tapered cone marked with rings at millimetre increments in diameter. The

139 regression of width of the $10^{\text {th }}$ chaetiger $(x)$ (body only, not including parapodia) versus tube-cap

140 mouth (aperture) $(y)$ was $y=1.202 x+0.0375\left(\mathrm{R}^{2}=0.79, \mathrm{~N}=17\right.$, aperture sizes 1.5 to $7 \mathrm{~mm}, 10^{\text {th }}$

141 chaetiger widths 1.34 to $5.08 \mathrm{~mm}$ ) (Fig. 1). Tube-cap aperture diameter thus can be used as a

142 proxy for body size in the field. The smallest individuals recorded had tube-cap apertures of

143 approximately $1 \mathrm{~mm}$. Even those individuals had established tubes with imbricate decoration 
144 and often a shell over the aperture, typical of Diopatra. Individuals with tubes 3 to $4.5 \mathrm{~mm}$ in

145 diameter appeared to be six to nine months old, therefore individuals with aperture diameters less

146 than $5 \mathrm{~mm}$ were designated as young of the year or recruits (see section 3.4.1 for confirmation of

147 this designation). We use the term 'recruitment' to refer to these individuals, which of course we

148 are recording several months after actual settlement (Bachelet 1990).

150 Small tube diameters do not mean that the worms are small. Individuals called young of the year

151 (aperture $<5 \mathrm{~mm}$ ) may have total body lengths $>8 \mathrm{~cm}$ based on the regression of $10^{\text {th }}$ chaetiger

152 width and body length of Pires et al. (2012b) for the similar species D. neapolitana. The

153 smallest individual of D. neapolitana found to have gametes was $\sim 14 \mathrm{~cm}$ long (Pires et al.

154 2012b). This corresponds crudely to a worm with a $10^{\text {th }}$ chaetiger width of $4 \mathrm{~mm}$ according to

155 their regression of body length on $10^{\text {th }}$ chaetiger width, and by our regression of $10^{\text {th }}$ chaetiger

156 width on tube aperture for D. biscayensis, this would be a worm with a tube aperture of $\sim 5 \mathrm{~mm}$.

157 Hence we consider animals with tube aperture diameters $\geq 5 \mathrm{~mm}$ to be adults.

\subsection{Size Frequency Analysis}

160 The size frequency data for each year and site were examined using the FiSAT II cohort

161 identification software (FiSAT II, Gayanilo et al. 2005). Bhattacharya's method was used to

162 generate initial estimates of means and standard deviations of potential component normal

163 distributions i.e. presumptive cohorts. It assigns a separation index to the presumptive cohorts.

164 Separation indices of $<2$ are typically unreliable, not statistically supported, and thus those

165 presumptive cohorts were rejected (see FiSAT II, Gayanilo et al. 2005). These initial estimates 
were then used as inputs into the NORMSEP routine which uses a maximum likelihood iteration routine to generate estimates of means, standard deviations and number of individuals per cohort.

The ELEPHAN I program for estimating growth parameters from size distributions (FiSAT II, Gayanilo et al. 2005) was used to assess growth rates. In only two populations, Arcachon and Verdon-sur-Mer, were there sufficiently large samples (>130 each year) with numbers of young of the year to do the analysis in all three years with aperture diameter measurements, 2011 to 2013. The ELEPHAN I program recognizes that in habitats with distinct seasonal differences in temperature, growth rates may vary with season (Pauley 1987). Given that Diopatra is a subtropical genus and members of the genus are known to cease activities such as feeding and tubebuilding under cold conditions (Mangum and Cox 1971, Myers 1972), reductions in growth during winter months are likely. The relevant parameters are the seasonal growth oscillation parameter $\mathrm{C}$ and the month of lowest growth due to low temperature ('WP' in ELEPHAN I) and as suggested, they were set to 0.8 and 0.1 respectively (Pauley 1987; de Graaf and Dekker 2006). The maximum size of $D$. biscayensis was set to $13 \mathrm{~mm}$ aperture diameter.

We view the growth rate estimates with caution because soft-bodied organisms can shrink as well as grow over time. Diopatra as a genus is known to lose its anterior and its posterior to predators (Berke et al. 2009, Pires et al. 2012a). During regeneration of lost body parts, depending on conditions, the worm may shrink, i.e. degrow. This also may occur with stress. Size thus is not a good measure of age for such soft-bodied organisms. This may be particularly true for older individuals which may have lost tissue to predators or experienced multiple periods of stress. The smaller the individual, the higher the probability may be of death rather than tissue 
loss with predation, so very small individuals may be more reliably assigned to age classes than larger individuals.

\subsection{Dispersal Distance}

To estimate dispersal capabilities of Diopatra biscayensis both within the contiguous range in the Bay of Biscay and their potential dispersal from the Bay of Biscay to the Normano-Breton Gulf in the English Channel, we carried out Lagrangian transport simulations using velocity fields from the IFREMER MARS2D models (Bailly du Bois and Dumas 2005; Lazure and Dumas 2008). Simulated larvae were released from known population locations and treated as passive particles. The larval duration and release period were based on our best estimate derived from the literature on D. neapolitana. We used information from the congener because the reproductive season of $D$. biscayensis is unknown, the species only having been described in 2012 (Fauchald et al. 2012). The older literature, particularly for the Atlantic coast of France, may contain observations ascribed to $D$. neapolitana that really are for $D$. biscayensis, because the two species are very similar in size and life habits, and the appearance of $D$. biscayensis is unresolved except to be after the 1920s and probably before the 1960s for at least the area of Arcachon, France (Berke et al. 2010). D. neapolitana reproduces from May to September in Portugal (Pires et al. 2012b) and the sperm microstructure is consistent with broadcast spawning (Conti et al. 2005). Cazaux (1973) working in Arcachon found larvae of Diopatra which he called D. neapolitana in the water column only from September to December. These may well have been larvae of D. biscayensis. The initial growth descriptions by all authors (Cazaux 1973, Conti and Massa 1998, Pires et al. 2012b) are congruent; larvae are lecithotrophic, spend 4 to 6 days in the water column, then are benthic with a tube, and by 3 months are $1.5 \mathrm{~cm}$ in length. 
Thus in the dispersal simulations we used a reproductive release period of September through

213 December with a maximum larval life of 6 days. These simulations provide a maximum

214 estimate of planktonic larval transport because they assume the larvae spend all of their time in

215 the surface layers of the ocean.

217 Two-dimensional velocity fields on a $250 \mathrm{~m}$ grid scale were available in 15 -minute increments over the period 2009-2012. Since most bays and peninsulas on this coast are $1 \mathrm{~km}$ or greater in size, flow within and around those features is resolved at this scale. The $250 \mathrm{~m}$ scale MARS2D models are nested inside a $700 \mathrm{~m}$ scale $2 \mathrm{D}$ model, which is nested inside a $4 \mathrm{~km}$ scale $3 \mathrm{D}$ model of the European shelf (Franck Dumas, pers. comm.). The $4 \mathrm{~km}$ scale 3D model used 8 tidal constituents at the open ocean boundary, and all models use meteorological forcing from the ARPEGE forecasts of Meteo-France (Lazure and Dumas 2008). The MARS models have been validated using oceanographic data (Lazure et al. 2009) and radionuclide plumes (Bailly du Bois and Dumas 2005). In our Lagrangian simulations, cohorts of 500 passive particles (proxies for larvae) were released each hour during the 7-hour period centered on high tides during three days around the new and full moon during the months of September to December in each of the years 2009 to 2012. Larvae were released from sites of known populations of D. biscayensis, were followed for 6 days, and were assumed to be competent to settle after the first day. Dispersal

230 simulations were carried out in the Lagrangian transport simulator Ichthyop Version 3 (Lett et al. 231 2008), using Euler's method with an integration time step of 1 minute. Dispersal potential was 232 estimated by determining the fraction of larvae in each cohort from each release location that 233 passed within $500 \mathrm{~m}$ radius of points along the coastline, spaced $1 \mathrm{~km}$ apart and $1 \mathrm{~km}$ offshore 234 during the period of larval competency (days 2-6 after release). These sampling locations were 
chosen in order to avoid possible artefacts associated with land boundaries of the numerical ocean models. Since the larvae in the simulation were proxies for potentially much larger cohorts of real larvae, they were allowed to continue dispersing for the entire 6-day period, even if they passed through one or more of the "capture" locations. Dispersal potential calculations were carried out in the R statistical language (Ikaha and Gentleman 1996, R Development Core Team 2007, Chambers 2008), using the spatial statistics library "spatstat" (Baddeley and Turner 2005); latitude /longitude to UTM conversion was carried out using the "clim.pact" library (Benestad 2004).

\section{Results}

\subsection{Population Densities}

\subsubsection{Bay of Biscay Populations}

Densities were greatest in Arcachon $\left(44.6585^{\circ} \mathrm{N}, 1.1423^{\circ} \mathrm{W}\right)$, Châtelaillon-Plage $\left(46.0597^{\circ} \mathrm{N}\right.$, $\left.1.0907^{\circ} \mathrm{W}\right)$, and the Baie du Bile $\left(47.4454^{\circ} \mathrm{N}, 2.4756^{\circ} \mathrm{W}\right)$ in all years, although the Plage de Gatseau $\left(45.80411^{\circ} \mathrm{N}, 1.22172^{\circ} \mathrm{W}\right)$ which we sampled only in 2013 , had the highest overall density $\left(111 \mathrm{~m}^{-2}\right)$ and the highest quadrat density $\left(360 \mathrm{~m}^{-2}\right)$ (Fig. 2). With the exception of La Trinité-sur-Mer $\left(47.5830^{\circ} \mathrm{N}, 3.0242^{\circ} \mathrm{W}\right)$, all populations censused in the Bay of Biscay had mean densities of greater than $1.7 \mathrm{~m}^{-2}$. Individuals separated by $<10 \mathrm{~cm}$ were common in all years implying that successful reproduction could occur in at least some cases. The population at La Trinité-sur-Mer had no young of the year in any of our censuses and with a mean nearest 
neighbor distance greater than $4 \mathrm{~m}$, the likelihood of successful reproduction is small (Table 1, Figs. 2, 3).

Most populations showed density changes of two to three fold between years, but none appeared to be declining by 5 fold or more except for the population at La Trinité-sur-Mer (Fig. 2).

Densities at La Trinité-sur-Mer declined by an order of magnitude in 2011 relative to 2010 and by a factor of 8 in 2012 relative to 2011 so that mean nearest neighbor distances rose dramatically from $0.4 \mathrm{~m}$ in 2010 to $4.3 \mathrm{~m}$ in 2013 as densities declined (Fig. 2). The populations at Arcachon and perhaps at Dolmen du Crapaud have decreasing mean densities but the magnitudes of the declines are less than three fold between years. Regressions of density versus time were significant for the populations at Arcachon, Dolmen du Crapaud and La Trinité-surMer (respective p values: $3.8 \times 10^{-6}, 4.3 \times 10^{-3}, 3.4 \times 10^{-15}$ ). However, for the populations at Arcachon and Dolmen du Crapaud, the $\mathrm{R}^{2}$ values were very small, 0.11 and 0.07 respectively; thus, the regressions explained only a small proportion of the variance. In contrast, the regression of density versus time for the population at La Trinité-sur-Mer had an $\mathrm{R}^{2}$ value of 0.39 .

\subsubsection{Normano-Breton Gulf Populations}

275 Unlike the Bay of Biscay populations, except for the terminal population at La Trinité-sur-Mer, all four populations in the Normano-Breton Gulf had mean densities per meter square of less than one and mean nearest neighbor distances $>1 \mathrm{~m}$ (Fig. 2). These distances among adults may greatly reduce the probability of fertilization success, depending upon sperm transfer (Levitan 
and Petersen 1995). The only population in which we saw any individual smaller than $5 \mathrm{~mm}$ in aperture diameter was at Sainte-Anne near Cherrueix in 2010 and 2012, where we found one young of the year in each year $(<5 \mathrm{~mm}$ aperture) (Fig. 3, Table 1). Mean nearest neighbor distances at Saint-Anne were between $1.1 \mathrm{~m}$ and $1.8 \mathrm{~m}$ (Fig. 2). All four Normano-Breton Gulf populations had mean aperture diameters as large or larger than those of the populations in the Bay of Biscay (Table 1). The population at Saint-Géran in the Baie de la Fresnaye was very small: in three hours of searching only 12 individuals were found. Mean nearest neighbour distances at Saint-Géran were $>4 \mathrm{~m}\left(\right.$ density $\left.<0.001 \mathrm{~m}^{-2}\right)$, and all individuals were large (Table $1)$.

\subsection{Size Frequency Distributions}

\subsubsection{Bay of Biscay Populations}

The most southern populations, Arcachon, Verdon-sur-Mer $\left(45.55123^{\circ} \mathrm{N}, 1.05893^{\circ} \mathrm{W}\right)$, and Plage de Gatseau on Île d'Oléron, are characterized by a high percentage of individuals $<5 \mathrm{~mm}$ tube aperture diameter (young of the year) and by no individuals over $10 \mathrm{~mm}$ tube aperture diameter (Fig. 3, Table 1). The more northern populations from Châtelaillon-Plage to the Dolmen du Crapaud near Billiers $\left(47.51528^{\circ} \mathrm{N}, 2.48445^{\circ} \mathrm{W}\right)$ rarely had more than $5 \%$ of the censused individuals in the $<5 \mathrm{~mm}$ tube aperture category and in one case no young of the year were found in a sample of over 100 individuals (Tharon Plage at Saint-Michel-Chef-Chef $\left.\left(47.1647^{\circ} \mathrm{N}, 2.17^{\circ} \mathrm{W}\right) 2011, \mathrm{n}=131\right)$. Individuals of $10 \mathrm{~mm}$ or more tube aperture diameter can be common in these more northern populations in contrast to those further south where few large individuals were found in three years (Fig. 3). Mean sizes were smaller at the southern sites, reflecting both a smaller upper size and a larger proportion of young of the year (Table 1, Fig. 3). 
302

303

304

305

306

307

308

The northernmost population in the continuous distribution is at La Trinité-sur-Mer and its population was dramatically different from all others in that no individuals $<8 \mathrm{~mm}$ tube aperture diameter were found in our surveys of 2010-2013, most individuals are $\geq 9 \mathrm{~mm}$ tube aperture diameter, and the population has decreased by almost two orders of magnitude since 2010 (Table 1, Figs. 2, 3).

\subsubsection{Normano-Breton Gulf Populations}

The populations of the Normano-Breton Gulf are more than $450 \mathrm{~km}$ from those of the Bay of Biscay. The coast between these two regions has areas of suitable habitat and we have searched intertidal locations north from La Trinité-sur-Mer in the Vilaine/Loire region of the Bay of Biscay to Jospinet in Saint-Brieuc Bay $\left(48.5515^{\circ} \mathrm{N}, 2.6066^{\circ} \mathrm{W}\right)$ on the English Channel side of the Brittany Peninsula, but we have found no Diopatra (Fig. 4). Additionally we have searched both the east and west sides of the Cotentin Peninsula in Normandy and again have found no Diopatra (Fig. 4). The four populations discovered to date in the Normano-Breton Gulf between Champeaux $\left(48.7327^{\circ} \mathrm{N}, 1.5521^{\circ} \mathrm{W}\right)$ and Saint-Géran $\left(48.6467^{\circ} \mathrm{N}, 2.2966^{\circ} \mathrm{W}\right)$ in the Baie de la Fresnaye are all dominated by large individuals and at only one site have we seen any young of the year or any individuals $<7 \mathrm{~mm}$ tube aperture diameter (Table1, Fig. 3: Sainte-Anne).

\subsection{Cohort Analysis}

Cohort analysis of size frequency distributions differed between the two southernmost populations and those further north in the Bay of Biscay, but in neither case did it prove to be very informative. Only at Arcachon could more than one cohort be resolved in all three years. 
In the case of Arcachon, with good densities of small individuals in all years sampled (Fig. 3), a peak centered on $3.4 \mathrm{~mm}$ with upper and lower $95 \%$ confidence limits of 4.6 and $2.2 \mathrm{~mm}$ could be resolved, which crudely corresponds to what we have designated as young of the year i.e. worms with tube apertures of $<5 \mathrm{~mm}$. As is clear from the size distributions of the populations (Fig. 3), in only a few cases is any coherent cohort size structure apparent; so, we restrict ourselves to merely recognizing individuals with very small apertures $(<5 \mathrm{~mm})$ as young of the year.

\subsection{Growth Rate and Lifespan Estimates}

\subsubsection{Estimates from FiSAT II ELEPHAN I}

The populations at Arcachon and Verdon-sur-Mer had numerous young of the year in all census years (Fig. 3) and thus could be used to estimate growth parameters. Growth parameters estimated from the FiSAT II ELEPHAN I algorithm for these populations suggest that by 12 months of age individuals would have an aperture diameter of $\sim 5 \mathrm{~mm}$ (Table 2). Size data relative to the presence of developing gametes exist for $D$. neapolitana, a very similar worm in terms of size (Pires et al. 2012b). In D. neapolitana, animals of $5 \mathrm{~mm}$ aperture diameter are $\sim 14$ $\mathrm{cm}$ long and are of reproductive size (Pires et al. 2012b, section 2.3). Choe (1960) reported very similar growth rates for a Japanese species of Diopatra, individuals reaching lengths of 12.4 to $13.9 \mathrm{~cm}$ in one year.

All census observations were made in June to mid-July depending on year and site. Assuming reproduction and recruitment from September through December (see Materials and Methods: 
2.5), the young of the year would be 5 to 10.5 months old at the time of census. Based on our calculated growth parameters these individuals would be expected to have aperture diameters between 2.0 and $4.3 \mathrm{~mm}$. This again corresponds to those we are designating as young of the year (Tables 1 and 2, Fig. 3).

\subsubsection{Field Data on Growth Increments and Lifespan}

Densities at most locales are too great to allow worms to be individually followed through time; so, neither lifespan nor growth rate can be estimated from known individuals. The densities at La Trinité-sur-Mer are sufficiently small that this could be done for 10 individuals recorded in 2011, 2012 and 2013 (Table 3). Members of this genus with sediment tubes rarely move; thus, if the individual is still alive, it should be at the previous year's coordinates \pm the GPS error (Brenchley 1975, Myers 1972). We therefore can use the data on this very limited number of individuals to ask whether the measured growth increments and lifespans are consistent with the estimates derived from FiSAT II. In 5 of the 10 cases, worms grew at rates crudely conforming to those estimated from ELEPHAN I assuming the animals were 1.5 to 2 years old when we first started tracking them in 2011 (Table 3). In the other 5 cases the worms either did not grow or shrank between years, which is consistent with soft-bodied organisms which often degrow. Note that 21 of the 28 individuals total seen in 2011 were never seen again. In 2012 and again in 2013, we searched without success areas 20 to $40 \mathrm{~m}$ in diameter centered on the coordinates of individuals found in 2011. We presume they are dead. Two of the seven individuals from 2011 that were seen in 2012 were not found in two days of searching in 2013, and again are presumed dead. Five survived the three year observation period (Table 3). These data also are consistent 
with a lifespan for D. biscayensis of 3 to 5 or more years which is also the estimate from FiSAT II (Table 2).

\subsection{Connectivity}

The results of the larval transport simulations are consistent with short-distance dispersal, typically $<50 \mathrm{~km}$ (Figs. 4, 5). Larvae released from sites adjacent to the northern geographic limit of D. biscayensis in the Vilaine/Loire region dispersed only within the local region during the 1 to 6 day larval period as is reflected in the rapidity of decrease in connectivity with distance (Figs. 4, 5). Larval connectivity was high close to the sites of origin, and declined by one order of magnitude for each $10 \mathrm{~km}$ of distance from the source (Fig. 5). No larvae escaped the Vilaine/Loire region (see the inset map on Fig. 4) in our simulations over the period 2009-2012. It is therefore highly unlikely that larvae from the Vilaine/Loire populations are the source of the populations in the Normano-Breton Gulf unless some additional mechanism of transport is involved. Within the Normano-Breton Gulf, dispersal was possible between the Sainte-Anne and Champeaux populations, and between the Quatre Vaux population in the Baie de l'Arguenon and the Saint-Géran population in the Baie de la Fresnaye. However the Sainte-Anne and Champeaux populations never exchanged larvae with Quatre Vaux or Saint-Géran in our simulations (Fig. 4). Therefore it is likely that the western two populations in the NormanoBreton Gulf were seeded independently from the eastern two populations. The decline of connectivity with distance in the Normano-Breton Gulf was 1 order of magnitude per $10 \mathrm{~km}$, indistinguishable from the rate of decline measured in the Vilaine/Loire region (Fig. 5). 
The Normano-Breton Gulf is an area of intense aquaculture activity, both of oysters and mussels. Several of the populations of $D$. biscayensis are seemingly spatially discrete and associated with bouchots. The population in the Baie de l'Arguenon at Quatre Vaux was used to test this association. Two of us searched for three hours, looking for individuals of $D$. biscayensis at three types of locales: (1) within $5 \mathrm{~m}$ of mussel seed rope deployments (chantiers) (Fig. 6), (2) within 5 to $15 \mathrm{~m}$ of mussel seed ropes, (3) further away from mussel seed ropes such as within 5 $\mathrm{m}$ of bouchots or in $20 \mathrm{~m}$ wide zones between rows of bouchots or in areas without bouchots. 96 individuals of $D$. biscayensis were found; $83 \%$ (80 individuals) were within $5 \mathrm{~m}$ of mussel seed ropes, $13.5 \%$ (13 individuals) were within 5 to $15 \mathrm{~m}$ of mussel seed ropes, and $3.5 \%$ (3

400 individuals) were found elsewhere.

\section{Discussion}

Diopatra biscayensis belongs to a genus of important ecosystem engineers (Woodin 1978, Berke et al. 2010, Woodin et al. 2010). At densities of 5 or more per $0.01 \mathrm{~m}^{2}$ the tube clumps of Diopatra alter both the biotic and physical characteristics of the habitat, acting as an ecosystem engineer (Bailey-Brock 1984; Luckenbach 1986; Woodin 1978, 1981). The populations along the French coast of the Bay of Biscay commonly exceed such densities (Fig. 2). D. biscayensis is common from Arcachon in southern France to the southern edge of Brittany and has disjunct populations without intermediate stepping stones in the Normano-Breton Gulf (Fig. 4). We 
sustainable? How is this reflected in their densities and size frequency distributions? What does this imply about the likelihood of the distribution of D. biscayensis in the eastern English Channel? Second, given the larval dispersal capabilities, how connected are the disjunct and continuous populations? If they are not connected by planktonic dispersal, are other sources of transport such as human assistance via aquaculture likely?

\subsection{Census and Geographic Distribution}

It is very difficult to dig intact individuals of Diopatra (Quatrefages 1866) but the tube-cap is distinctive and the diameter of the aperture is related to worm size (Fig. 1) so both densities and size distributions can be surveyed in the field. The continuous biogeographic range of $D$. biscayensis is from Arcachon $\left(44.65^{\circ} \mathrm{N}, 1.13333^{\circ} \mathrm{W}\right)$ in the south of France on the Bay of Biscay to La Trinité-sur-Mer $\left(47.5826^{\circ} \mathrm{N}, 3.02677^{\circ} \mathrm{W}\right)$ in southern Brittany. Populations disjunct from those of the Bay of Biscay exist at four sites in the western English Channel in the Normano-Breton Gulf (Fig. 4). Individuals identified as D. biscayensis from the Bay of Biscay and Normano-Breton Gulf are morphologically identical (Fauchald et al. 2012), so we consider them all to be one species.

\subsection{Density, Recruitment, and Size Structure in the Bay of Biscay}

The populations of Diopatra biscayensis along the French coast in the Bay of Biscay differ in the frequency of young of the year each year. The most southern populations (Arcachon and Verdon-sur-Mer) have a higher proportion of young of the year than those further north (Fig. 3). In all years during this study, 2010 to 2013, within the populations in the Bay of Biscay, 
complete absence of young of the year was extremely rare, seen only once at Tharon Plage in 2011 (Fig. 3, Table 1). The one exception to this pattern of recruitment success in the Bay of Biscay was the terminal population at La Trinité-sur-Mer where no individuals smaller than 8 mm tube aperture have been recorded (Fig. 3). Densities at La Trinité-sur-Mer are decreasing rapidly; over $75 \%$ of the adults seen in 2011 were gone by 2012 and the density in 2011 was one-tenth that of 2010 (Fig. 2). Our estimates of growth suggest that individuals $8 \mathrm{~mm}$ in aperture diameter are 1.5 to 2 years old (Table 2); so, the population we found in 2010 may reflect a recruitment event in 2009 or earlier. Based on our previously published metapopulation models of D. biscayensis (Berke et al. 2010, Wethey et al. 2011), the failure of this population does not appear to be due to either winter mortalities of juveniles or failure of reproduction in cool summers since populations $40 \mathrm{~km}$ to the east are highly successful with consistent presence of young of the year (Table 1, Fig. 3) and much higher densities (Fig. 2). A more likely explanation is that the local population density is too low for successful reproduction and dispersal distances are too great for recruitment from the larger populations to the east and south (Levitan and Petersen 1995) (Fig. 4, 5). For example, in both 2012 and 2013 no individual at La Trinité-sur-Mer was as close as $4 \mathrm{~m}$ to another. Given a lifespan of 3 to 5 years or more (Table 2), the population will display a demographic storage effect of adults present but no successful local reproduction. With short distance dispersal distances such a population may derive from a rare recruitment event with much higher than normal dispersal distances or survivorships (Wethey et al. 2011). We did not see any larval transport from nearby reproductive populations to La Trinité-sur-Mer in our simulations of the years 2009-2012 (Fig. 4 and 5), so the event likely occurred before 2009. 
The distribution of sizes also differs across the populations in the Bay of Biscay with the southern populations at Arcachon and Verdon-sur-Mer having both smaller mean apertures and smaller maximum size than in populations further north (Table 1, Fig. 3). The mean size difference is expected because the southern populations have larger proportions of young of the year, 0.10 to 0.27 in 2011 to 2013 versus 0.01 to 0.075 at Châtelaillon-Plage to Dolmen du Crapaud (ignoring the 0.0 in 2011 at Tharon-Plage). The difference in maximum size (Table 1) may well reflect a difference in disturbance or predation in the southern populations and thus more frequent episodes of regeneration. We have no data to support or refute this proposition but it seems most likely given the frequency with which this genus is known to lose tissue (Berke and Woodin 2008, Berke et al. 2009, Pires et al. 2012a).

\subsection{Dispersal and Connectivity}

Our dispersal simulations suggest that dispersal is likely to be less than $50 \mathrm{~km}$ in scale but varies with both wind and tidal conditions as seen in other simulation studies (Ayata et al. 2009, 2010; Dubois et al. 2007; Gilg and Hilbish 2002). Within the Bay of Biscay, populations are sufficiently close that some larval input from adjacent populations is likely (Fig. 4, 5). This is also true for the populations within the Normano-Breton Gulf (Fig. 4, 5). However the simulations indicate that populations within the Bay of Biscay have no larval exchange with those of the Normano-Breton Gulf. The lack of connectivity that we observed between the Vilaine/Loire region of the Bay of Biscay and the Normano-Breton Gulf is consistent with larval simulations by Ayata et al. (2010). Their simulations were for different seasons from ours (January - August), their larval durations were longer (2 - 4 weeks), and they observed no connectivity between the Vilaine/Loire region of the Bay of Biscay and the Normano-Breton 
Gulf in 5 years of simulations, 2001-2005 (Ayata et al. 2010). The average north-south dispersal distance observed in their 2-week simulations was $50 \mathrm{~km}$, consistent with our estimates from the decline in connectivity with distance (Fig. 5). Therefore we believe that planktonic larval dispersal cannot account for the origin of the Normano-Breton Gulf populations

\subsection{Normano-Breton Gulf Populations versus the Bay of Biscay Populations}

Along most of the French Bay of Biscay coast there is abundant suitable habitat for Diopatra. We had previously projected a northward expansion, facilitated by larval dispersal as temperature conditions became more permissive, leading to possible expansion into the Normano-Breton Gulf by perhaps 2050 and certainly by 2099 (Berke et al. 2010, Wethey et al. 2011). However Diopatra is already present in the Normano-Breton Gulf. Based on our connectivity analysis and the lack of stepping stone populations around the Brittany peninsula, one cannot invoke larval dispersal to bridge the over $450 \mathrm{~km}$ distance from the Bay of Biscay (Fig. 4 and 5). One of the four Normano-Breton Gulf populations (Sainte-Anne) appears to be sustainable since it has existed since 2001-2 (S. Dubois, unpub.), and we have twice seen young of the year (2010 and 2012), although the densities are very low $\left(0.2 \mathrm{~m}^{-2}\right)$ with mean nearest neighbor distance of $1.1 \mathrm{~m}$ in 2013 (Fig. 2). In spring 2014 Dubois again found young of the year at Sainte-Anne. The other three populations resemble that of La Trinité-sur-Mer since no young of the year have been seen, densities are low $\left(<0.1\right.$ ind. $\left.\mathrm{m}^{-2}\right)$ with nearest neighbor distances often 2 meters or larger greatly reducing the probability of sperm transfer (Levitan and Petersen 1995), and in two of the three populations we found relatively few individuals despite long searches (Quatre Vaux: N=107; Saint-Géran: N=12) (Figs. 2, 3). The population densities and proportion of young of the year are thus strikingly different from the Bay of Biscay, with 

those of the Normano-Breton Gulf appearing to be not or only marginally self-sustainable (Fig. $2,3)$.

\subsection{Mussel Culture and Biogeography of Diopatra biscayensis: Normano-Breton Gulf}

The Normano-Breton Gulf is one of the most important mussel grow-out areas of France but limited natural recruitment has led to the use of imported seed to support the industry in this region. Transplantation of seed from distant grow-out areas is common in Europe (FAO 2013, Maguire et al. 2007). Over $90 \%$ of the seed used in mussel culture in Brittany comes from the Marennes-Oléron Bay in the Bay of Biscay where the densities of D. biscayensis can exceed 300 ind. $\mathrm{m}^{-2}$ and mean density in 2013 was 111 ind. $\mathrm{m}^{-2}$ (Figs. 2, 4: Gatseau site GA). Mussels in the Bay of Mont-Saint-Michel have an AOC designation which requires that the mussel seed ropes be only from the region between Île d'Oléron and Le Pointe de l'Aiguillon (Marteil 1979). This very restricted area includes the Gatseau site and has abundant Diopatra. In both the seed collection areas and in the grow out areas, it is common to see seed collection ropes lying on the ground after becoming detached from the rack and it is equally common to see older seed ropes in the grow-out areas which also have become detached. Transport of juvenile or older $D$. biscayensis on ropes is easily possible since $D$. biscayensis attaches debris, including ropes, to its tube-cap and will extend its tube onto such structures.

\subsubsection{Association with Mussel Seed Ropes}

If the scenario of human-assisted-transport from mussel seed collection areas in the Vendée / Charente-Maritime regions in the Bay of Biscay to mussel grow-out areas in the Normano- 
Breton Gulf is correct, then one would expect the population of D. biscayensis to be spatially associated with the mussel seed ropes and not to other portions of the mussel culture installations. Consistent with the human-assisted-transport hypothesis, over $83 \%$ of the individuals found were within $5 \mathrm{~m}$ of mussel seed ropes in the population at Quatre Vaux in the Bay of Arguenon (see Results: 3.6).

\subsubsection{Normano-Breton Gulf Populations}

The population of Diopatra biscayensis near the Sainte-Anne sabellariid reef at Cherrueix was already well-established when Dubois discovered it in 2001-2. It is near to mussel culture areas with bouchots; so, presumably it originated via human-assisted-transport associated with aquaculture. At this site, it is common to find two or more individuals within $0.25 \mathrm{~m}^{2}$ so it seems likely that this population has sufficient density for fertilization success; over 38\% of the 194 individuals measured in 2013 for example shared a $0.25 \mathrm{~m}^{2}$ with another individual and the average nearest neighbor distance was $1.1 \mathrm{~m}$. This is a higher population density and more frequent occurrence of multiple individuals within $0.25 \mathrm{~m}^{2}$ than any of the other populations in the Normano-Breton Gulf (Fig. 2). Like the population at Sainte-Anne, the populations at Quatre Vaux and at St-Géran are near mussel culture areas; the population at Champeaux is not. Our dispersal simulations indicate that the Champeaux population may have been established as a result of larval dispersal from the Sainte-Anne population which is less than $5 \mathrm{~km}$ distant (Fig. 4). Ayata et al. (2009) also showed extensive larval exchanges between Sainte-Anne and Champeaux Sabellaria alveolata populations, consistent with our results. 
The dispersal simulations indicate that there was no connectivity between the two populations in the western Normano-Breton Gulf (Saint-Géran and Quatre Vaux) and the two eastern populations (Sainte-Anne and Champeaux) during the period 2009-2012 (Fig. 4). This result implies that the western populations represent a colonization event independent of the establishment of the eastern populations. Since there are extensive bouchots and chantiers at Saint-Géran and Quatre Vaux, and since the D. biscayensis at Quatre Vaux are clustered near to the chantiers (see Results 3.6), we believe that direct transport to this region is more likely than recruitment of larvae from the Sainte-Anne and Champeaux populations.

\subsection{Conclusions}

The importance of human intervention in marine biogeography has been increasing as a result of larval transport by ballast water (Carlton 1985), adult transport on ballast rock (Brawley et al. 2009), introduction of structures that can be used as stepping stones (Johannesson and Warmoes 1990, Moschella et al. 2005, and Firth et al. 2013), and introduction of commercially harvested species in new regions: Japanese oysters in British Columbia in Canada and Europe (Quayle 1964, Grizel and Héral 1991), the mussel Mytilus galloprovincialis in California (Rawson et al. 1999) and South Africa (Griffiths et al. 1992), the carpet clam Tapes philippinarum worldwide (Flassch and Leborgne 1994, Quayle 1964). As a consequence, there have been unanticipated introductions of associated species: e.g. gastropods Rapana venosa and Ocinebrellus inornatus in the bay of Quiberon, South Brittany (Bouget et al. 2001, Joly et al. 2002) or Cyclope neritea (Bachelet et al. 2004) in the whole Bay of Biscay, Crepidula fornicata into Great Britain and subsequently into France (Blanchard 1997), all introduced because of oyster and mussel cultures. Here we have shown that disjunct populations of Diopatra beyond a regional biogeographic 
boundary are in sites where there is yearly trans-regional transport of aquaculture materials. Thus aquaculture provides a mechanism for the bridging of a regional biogeographic boundary. Upwelling zones form biogeographic boundaries of many warm-water species, and penetration of those boundaries usually occurs only after extreme events (e.g. Lima et al. 2006, Sousa et al. 2012). However, as we have shown here, continuous human- assisted transport of aquaculture materials across oceanographic boundaries has the potential to alter fundamentally the biogeographic structure of our coastlines. The transport of aquaculture materials is a fundamentally different process from the introduction of stepping-stone structures (e.g. Johannesson and Warmoes 1990, Moschella et al. 2005, and Firth et al. 2013) because the necessary sedimentary habitat for infauna like Diopatra already exists, however a natural mechanism of larval transport does not (e.g. Fig 4). Our metapopulation models of the effects of future climates on biogeography indicated that Diopatra would invade the English Channel by the mid $21^{\text {st }}$ century (Berke et al. 2010, Wethey et al. 2011), but this time scale has been cut in half by human-assisted transport.

\section{Acknowledgements}

This research was supported by grants from NSF (OCE1039513), NOAA (NA04NOS4780264), NASA (NNX07AF20G and NNX11AP77G). We thank the MARS modeling group and the PREVIMER Project staff at IFREMER for their hospitality and in particular F. Dumas and F. Lecornu for making available model runs and the developmental version of Ichthyop. We also thank D. Gerla for pointing out the Diopatra populations in les Quatre Vaux. 
592

593

594

595

596

597

598

599

600

601

602

603

604

605

606

607

608

609

610

611 Bachelet, G. 1990. Recruitment of soft-sediment infaunal invertebrates: the importance of 612 juvenile benthic stages. La mer 28: 199-210.

613

Author contributions: DSW, SAW, and SFD conceived the idea. DSW and SAW carried out the majority of the field surveys. SFD located several of the populations and did the initial surveys at those locations. DSW wrote and ran the dispersal simulations. SAW did the size analysis and led the writing.

\section{Literature Cited}

Arias, A., N. Anadón, and H. Paxton. 2010. New records of Diopatra marocensis (Annelida:

Onuphidae) from northern Spain. Zootaxa 2691: 67-68.

Ayata, S.-D., C. Ellien, F. Dumas, S. Dubois, and E. Thiébaut. 2009. Modelling larval dispersal and settlement of the reef-building polychaete Sabellaria alveolata: Continental Shelf Research 29: $1605-1623$.

Ayata, S.-D., P. Lazure, and E. Thiébaut. 2010. How does the connectivity between populations mediate range limits of marine invertebrates? A case study of larval dispersal between the Bay of Biscay and the English Channel (North-East Atlantic). Progress in Oceanography 87: 18-36. 
614 Bachelet, G., B. Simon-Bouhet, C. Desclaux, P. Garcia-Meunier, G. Mairesse, X. de

615 Montaudouin, H. Raigné, K. Randriambao, P.G. Sauriau, and F. Viard. 2004. Invasion of the

616 eastern Bay of Biscay by the nassariid gastropod Cyclope neritea: origin and effects on

617 resident fauna. Marine Ecology Progress Series 276: 147-169.

618

619 Baddeley, A. and R. Turner. 2005. Spatstat: an R package for analyzing spatial point patterns.

620 Journal of Statistical Software 12(6): 1-42.

621

622

Bailey-Brock, J. 1984. Ecology of the tube-building polychaete Diopatra leuckarti Kinberg,

623

1865 (Onuphidae) in Hawaii: community structure, and sediment stabilizing properties.

624

Zoological Journal of the Linnean Society, London 80: 191-199.

625

626

Bailly du Bois, P. and F. Dumas. 2005. Fast hydrodynamic model for medium- and long-term

627

dispersion in seawater in the English Channel and southern North Sea, qualitative and

628 quantitative validation by radionuclide tracers. Ocean Modelling 9: 169-210.

629

630

Benestad, R. E. 2004. Empirical-statistical downscaling in climate modeling. Eos 85: 417.

631

632 Berke, S. K., and S. A. Woodin. 2008. Tube decoration may not be cryptic for Diopatra cuprea

633 (Polychaeta: Onuphidae). Biological Bulletin 214: 50-56.

634 
635

636

637

638

639

640

641

642

643

644

645

646

647

648

649

650

651

652

653

654

655

656

Berke, S. K., V. Cruz, and R. W. Osman. 2009. Sublethal predation and regeneration in two onuphid polychaetes: patterns and implications. Biological Bulletin 217: 242-252.

Berke, S. K., A. R. Mahon, F. P. Lima, K. M. Halanych, D. S. Wethey, and S. A. Woodin. 2010. Range shifts and species diversity in marine ecosystem engineers: patterns and predictions for European sedimentary habitats. Global Ecology \& Biogeography 19: 223-232.

Blanchard, M. 1997. Spread of the slipper limpet Crepidula fornicata (L. 1758) in Europe.

Current state and consequences. Scientia Marina 61 (Supplement 2): 109-118.

Bouget J.-F., P. Camus, J.-P. Joly. 2001. Ocinebrellus inornatus (Recluz, 1851), Rapana venosa

(Valenciennes, 1846) : deux nouveaux gastéropodes introduits dans la Baie de Quiberon.

http://archimer.ifremer.fr/doc/00092/20360/, accessed 2013 October 28. (1)

Brawley, S. H., J. A. Coyer, A. M. H. Blakeslee, G. Hoarau, L. E. Johnson, J. E. Byers, W. T.

Stam, and J. L. Olsen. 2009. Historical invasions of the intertidal zone of Atlantic North America associated with distinctive patterns of trade and emigration. Proceedings of the National Academy of Sciences 106: 8239-8244. (1)

Brenchley, G.A. 1975. Competition, disturbance, and community structure: the importance of physical structure in a marine epifaunal assemblage. Masters thesis, University of Maryland, College Park, MD, 69pp. 
658 Carlton, J. T. 1985. Transoceanic and interoceanic dispersal of coastal marine organisms: the 659 biology of ballast water. Oceanography and Marine Biology Annual Review 23: 313-371.

660

661 Cazaux, C. 1973. Cycle et distribution des larves de polychetes; caracteres du meroplancton des 662 differents types de masses d'eaux du bassin d'Arcachon. Bull. Ecol. IV: 257-275.

663

664 Chambers, J. M. 2008. Software for Data Analysis. Springer, NY.

665

666 Choe, S. 1960. On the life history of the polychaete worm Diopatra neapolitana Delle Chiaje.

667 Bulletin of the Japanese Society for Scientific Fisheries 26: 430-437.

668

669 Conti, G. and F. Massa. 1998. Esperienze di allevamento del polichete Diopatra neapolitana

670 Delle Chiaje, 1841 Nella Laguna di S. Gilla (Sardegna Meridionale). Biol. Mar. Medit. 5: 14736711480.

672

673 Conti, G., F. Loffredo, and M. S. Lantini. 2005. Fine structure of the spermatozoon of Diopatra 674 neapolitana (Polychaeta, Onuphidae). Zoomorphology 124: 155-160.

675

676 Diggle, P. J. 1975. Robust density estimation using distance methods. Biometrika 62: 39-48. 
Dubois, S., T. Comtet, C. Retière, and E. Thiébaut. 2007. Distribution and retention of

679

680

681

682

683

684

685

686

687

688

689

690

691

692

693

694

695

696

697

698

699

Sabellaria alveolata larvae (Polychaeta: Sabellariidae) in the Bay of Mont-Saint-Michel, France. Marine Ecology Progress Series 346: 243-254.

Fauchald, K., S. K. Berke, and S. A. Woodin. 2012. Diopatra (Onuphidae: Polychaeta) from intertidal sediments in southwestern Europe. Zootaxa 3395: 47-58.

FAO Fisheries \& Aquaculture - Cultured Aquatic Species Information Programme - Mytilus edulis (Linnaeus, 1758). www.fao.org/fishery/culturedspecies/Mytilus_edulis/en\#tcNA00FE, accessed 2013 August 7.

Firth et al. 2013. Climate change and adaptational impacts in coastal systems: the case of sea defences. Environmental Science: Processes and Impacts 15: 1665-1670.

Flassch, J. P. and Y. Leborgne. 1994. Introduction in Europe, from 1972 to 1980, of the Japanese Manila clam (Tapes philippinarum) and the effects on aquaculture production and natural settlement. ICES Marine Science Symposium 194: 92-96.

Gayanilo, F.C., Jr, P. Sparre, and D. Pauly. 2005. FAO-ICLARM Stock Assessment Tools II (FiSAT II). Revised verion. FAO Computerized Information Series (Fisheries). No. 8, Rome, FAO, $168 \mathrm{p}$ 
700

701

702

703

704

705

706

707

708

709

710

711

712

713 Grizel, H. and M. Héral. 1991. Introduction into France of the Japanese oyster (Crassostrea

714 gigas). J. Cons. int. Explor. Mer 47: 399-403.

715

716

717

718

Gilg, M. R. and T. J. Hilbish. 2002. The geography of marine larval dispersal: coupling genetics with fine-scale physical oceanography. Ecology 84: 2989-2998.

Glemarec, M. 1979. Les fluctuations temporelles des peuplements benthiques liees aux fluctuations climatiques. Oceanologica Acta 2: 365-371.

de Graaf, G. J. and P. Dekker. 2006. A simple spreadsheet model to incorporate seasonal growth into length-based stock assessment methods. NAGA WorldFish Center Quarterly 29: 46-54.

Griffiths, C. L., P. A. R. Hockey, C. Van Erkom Shurink, and P. J. Le Roux. 1992. Marine invasive aliens on South African shores: implications for community structure and trophic functioning. South African Journal of Marine Science 12: 713-722.

Ikaha, R. and R. Gentleman. 1996. R: a language for data analysis and graphics. Journal of Computational and Graphical Statistics 5: 299-314. 
Johannesson and Warmoes. 1990. Rapid colonization of Belgian breakwaters by the direct developer, Littorina saxatilis (Olivi) (Prosobranchia, Mollusca). Hydrobiologia 193: 99-108.

Joly J.-P., J.-F. Bouget and T. Hirata. 2002. Le gastéropode prédateur Rapana venosa: point sur les connaissances et expérimentations au laboratoire.

http://archimer.ifremer.fr/doc/00016/12699/, accessed 2013 October 28.

Lazure, P. and F. Dumas. 2008. An external-internal mode coupling for a 3D hydrodynamical model for applications at regional scale (MARS). Advances in Water Resources 31: 233-250.

Lazure, P., V. Garnier, F. Dumas, C. Herry, and M. Chifflet. 2009. Development of a hydrodynamic model of the Bay of Biscay. Validation of hydrology. Continental Shelf Research 29: 985-997.

Lett, C., P. Verley, C. Mullon, C. Parada, T. Brochier, P. Penven, and B. Blanke. 2008. A Lagrangian tool for modelling ichthyoplankton dynamics. Environmental Modelling and Software 23: 1210-1214.

Levitan, D. R. and C. Petersen. 1995. Sperm limitation in the sea. Trends in Ecology and Evolution 10: 228-231. 
741

742

743

744

745

746

747

748

749

750

751

752

753

754

755

756

757

758

759

760

761

762

Lima, F. P., N. Queiroz, P. A. Ribeiro, S. J. Hawkins, and A. M. Santos. 2006. Recent changes in the distribution of a marine gastropod, Patella rustica Linnaeus, 1758, and their relationship to unusual climatic events. Journal of Biogeography 33: 812-822.

Luckenbach, M. W. 1986. Sediment stability around animal tubes: the roles of hydrodynamic processes and biotic activity. Limnology and Oceanography 31: 779-787.

Maguire, J. A., T. Knights, G. Burnell, T. P. Crowe, F. O'Beirn, D. McGrath, M. Ferns, N.

McDonough, N. McQuaid, B. O'Connor, R. Doyle, C. Newell, R. Seed, A. Smaal, T. O'Carroll, L. Watson, J. Dennis, and M. O'Cinneide. 2007. Management recommendations for the sustainable exploitation of mussel seed in the Irish Sea. Marine Environment and Health Series no. $31,83 p p$.

Mangum, C. P. and C. D. Cox. 1971. Analysis of the feeding response in the onuphid polychaete Diopatra cuprea (Bosc). Biological Bulletin 140: 215-229.

Marteil, L. 1979. La conchyliculture francaise. 3. L'ostreiculture et la mytiliculture. Revue des Travaux de l'Institut des Pêches Maritimes 43(1): 10-130.

Moschella et al. 2005. Low-crested coastal defence structures as artificial habitats for marine life: using ecological criteria in design. Coastal Engineering 52: 10531071. 
764

765

766

767

768

769

770

771

772

773

774

775

776

777

778

779

780

781

782

783

Myers, A. 1972. Tube-Worm-Sediment relationships of Diopatra cuprea

(Polychaeta:Onuphidae). Marine Biology 17: 350-356.

Pauley, D. 1987. A review of the ELEFAN system for analysis of length-frequency data in fish and aquatic invertebrates. In D. Pauly and G. R. Morgan (eds.) Length-based methods in fisheries research. ICLARM Conference Proceedings 13, 468 p. International Center for Living Aquatic Resources Management, Manila, Philippines, and Kuwait Institute for Scientific Research, Safat, Kuwait, pp. 7-34.

Pires, A., H. Paxton, V. Quintino, and A. M. Rodrigues. 2010. Diopatra (Annelida: Onuphidae) diversity in European waters with the description of Diopatra micrura, new species. Zootaxa 2395: 17-33.

\section{Pires, A., R. Freitas, V. Quintino, and A. M. Rodrigues. 2012a. Can Diopatra neapolitana}

(Annelida: Onuphidae) regenerate body damage caused by bait digging or predation? Estuarine, Coastal and Shelf Science 110: 36-42.

Pires, A., F. Gentil, V. Quintino, and A. M. Rodrigues. 2012b. Reproductive biology of Diopatra neapolitana (Annelida, Onuphidae), an exploited natural resource in Ria de Aveiro (Northwestern Portugal). Marine Ecology 33: 56-65. 
785 Prou, J. and P. Goulletquer. 2002. The French mussel industry: present status and perspectives.

786 Proceedings of the First International Mussel Forum Aquaculture Canada super(OM) 2002,

787 Charlottetown, PEI, 17-20 September 2002 102: 17-23.

788

789 Quatrefages, A. d. 1866. Histoire naturelle des Annelés marins et d'eau douce. Annélides et

790 Géphyriens. Librarie Encyclopédique de Roret, Paris.

791

792

Quayle, D. B. 1964. Distribution of introduced marine Mollusca in British Columbia waters.

Journal of the Fisheries Research Board of Canada 21: 1155-1181.

794

795 R development Core Team. 2007. R: A language and environment for statistical computing. R

796 Foundation for Statistical Computing, Vienna, Austria. http://www.r-project.org, accessed 2013

797 October 28.

798

799 Rawson, P. D., V. Agrawal, and T. J. Hilbish. 1999. Hybridization between the blue mussels

800 Mytilus galloprovincialis and M. trossulus along the Pacific coast of North America: evidence

801 for limited introgression. Marine Biology 134: 201-211.

802 
803

804

805

806

807

808

809

810

811

812

813

814

815

816

817

818

819

820

821

822

823

824

Rodrigues, A. M., A. Pires, S. Mendo, and V. Quintino. 2009. Diopatra neapolitana and

Diopatra marocensis from the Portuguese coast: Morphological and genetic comparison.

Estuarine, Coastal and Shelf Science 85: 609-617.

Sousa, L. L., R. Seabra, D. S. Wethey, R. Xavier, N. Queiroz, S. Zenboudji, and F. P. Lima.

2012. Fate of a climate-driven colonisation: Demography of newly established populations of the limpet Patella rustica Linnaeus, 1758, in northern Portugal. Journal of Experimental Marine Biology and Ecology 438: 68-75.

Wethey, D. S. and S. A. Woodin. 2008. Ecological hindcasting of biogeographic responses to climate change in the European intertidal zone. Hydrobiologia 606: 139-151.

Wethey, D. S., S. A. Woodin, T. J. Hilbish, S. J. Jones, F. P. Lima, and P. M. Brannock. 2011.

Response of intertidal populations to climate: Effects of extreme events versus long term change.

Journal of Experimental Marine Biology and Ecology 400: 132-144.

Woodin, S. A. 1978. Refuges, disturbance, and community structure: a marine soft-bottom example. Ecology 59: 275-284.

Woodin, S. A. 1981. Disturbance and community structure in a shallow water sand flat. Ecology 62: 1052-1066. 
825 Woodin, S. A., D. S. Wethey, and N. Volkenborn. 2010. Infaunal hydraulic ecosystem engineers:

826 cast of characters and impacts. Integrative and Comparative Biology 50: 176-187.

827

828 
829 Table 1. Tube-cap aperture diameters (mm) (2011 to 2013) (means and ranges) of Diopatra

830 biscayensis along the Atlantic coast of France. 'na' no data for that site for that year. Sites

831 within the Bay of Biscay are arranged from south (Arcachon) to north (La Trinité-sur-Mer),

832 while those in the Normano-Breton Gulf are west (Saint-Géran) to east (Champeaux).

833

\begin{tabular}{|c|c|c|c|c|c|c|c|}
\hline \multicolumn{8}{|c|}{ Aperture Diameters: Means and Ranges (mm) } \\
\hline Bay of Biscay & 2011 & 2012 & 2013 & $\begin{array}{l}\text { Normano- } \\
\text { Breton } \\
\text { Gulf }\end{array}$ & 2011 & 2012 & 2013 \\
\hline Arcachon & $\begin{array}{c}5.4 \\
\text { (2 to } 9 \text { ) }\end{array}$ & $\begin{array}{c}5.6 \\
\text { (1 to } 10)\end{array}$ & $\begin{array}{c}5.95 \\
\text { (2 to } 8.5 \text { ) }\end{array}$ & $\begin{array}{l}\text { Saint- } \\
\text { Géran }\end{array}$ & na & na & $\begin{array}{c}9.7 \\
\text { (9 to } 10.5 \text { ) }\end{array}$ \\
\hline Verdon-sur-Mer & $\begin{array}{c}6.4 \\
\text { (3 to } 9 \text { ) }\end{array}$ & $\begin{array}{c}5.8 \\
\text { (2 to } 10)\end{array}$ & $\begin{array}{c}6.2 \\
\text { (3 to } 8.5 \text { ) }\end{array}$ & $\begin{array}{l}\text { Quatre } \\
\text { Vaux }\end{array}$ & na & $\begin{array}{c}10.3 \\
\text { (8 to } 12)\end{array}$ & $\begin{array}{c}9.6 \\
\text { (8 to } 12 \text { ) }\end{array}$ \\
\hline Plage de Gatseau & na & na & $\begin{array}{c}4.8 \\
(1.5 \text { to } 10)\end{array}$ & $\begin{array}{l}\text { Sainte- } \\
\text { Anne }\end{array}$ & na & $\begin{array}{c}9.6 \\
(3.5 \text { to } 12)\end{array}$ & $\begin{array}{c}9.2 \\
\text { (6 to } 11)\end{array}$ \\
\hline Châtelaillon-Plage & $\begin{array}{c}7.1 \\
\text { (3 to } 10)\end{array}$ & $\begin{array}{c}8.6 \\
\text { (3 to } 12 \text { ) }\end{array}$ & $\begin{array}{c}7.3 \\
(2 \text { to } 11)\end{array}$ & Champeaux & $\begin{array}{c}8.9 \\
\text { (7 to } 12 \text { ) }\end{array}$ & $\begin{array}{c}10.3 \\
\text { (9 to } 12 \text { ) }\end{array}$ & $\begin{array}{c}9.75 \\
\text { (8 to } 12)\end{array}$ \\
\hline Tharon Plage & $\begin{array}{c}7.5 \\
\text { (5 to } 9)\end{array}$ & $\begin{array}{c}7.9 \\
\text { (3 to } 12)\end{array}$ & $\begin{array}{c}7.6 \\
\text { (2 to } 10.5 \text { ) }\end{array}$ & & & & \\
\hline Le Pouliguen & na & $\begin{array}{c}9.7 \\
\text { (2 to } 11.5)\end{array}$ & $\begin{array}{c}8.1 \\
\text { (4 to } 11)\end{array}$ & & & & \\
\hline Baie du Bile & $\begin{array}{c}8 \\
\text { (2 to } 10)\end{array}$ & $\begin{array}{c}8.5 \\
\text { (4 to } 12)\end{array}$ & $\begin{array}{c}8.1 \\
\text { (3 to } 11)\end{array}$ & & & & \\
\hline $\begin{array}{l}\text { Dolmen du } \\
\text { Crapaud }\end{array}$ & $\begin{array}{c}7.3 \\
\text { (3 to } 11 \text { ) }\end{array}$ & $\begin{array}{c}8.6 \\
\text { (2 to } 11)\end{array}$ & $\begin{array}{c}8.1 \\
\text { (1.5 to } 11)\end{array}$ & & & & \\
\hline La Trinité-sur-Mer & $\begin{array}{l}8.9 \\
\text { (8 to } 11 \text { ) }\end{array}$ & $\begin{array}{c}9.8 \\
\text { (8 to } 11)\end{array}$ & $\begin{array}{c}9.3 \\
\text { (8 to } 11)\end{array}$ & & & & \\
\hline
\end{tabular}

834 
836 Table 2. Growth estimates from FiSAT ELEPHAN I algorithm. Estimated means and standard

837 deviations in millimetres of aperture diameters at yearly intervals calculated from growth

838 constants (K and D) for populations at Arcachon and Verdon-sur-Mer using ELEPHAN I. Mean

839 calculated $\mathrm{K}$ is 0.8 per year, ranging from 0.77 to 0.92 . Calculated $\mathrm{D}$ is 0.77 .

\begin{tabular}{|c|c|}
\hline Estimated Age & $\begin{array}{c}\text { Estimated Aperture Diameter } \\
\text { Mean (std dev) }\end{array}$ \\
\hline 12 months & $4.9(0.4)$ \\
\hline 24 months & $8.5(0.4)$ \\
\hline 36 months & $10.6(0.3)$ \\
\hline 48 months & $11.7(0.2)$ \\
\hline 60 months & $12.3(0.2)$ \\
\hline 72 months & $12.6(0.1)$ \\
\hline
\end{tabular}

840 
841 Table 3. Sizes in aperture diameter $(\mathrm{mm})$ of known individuals at the northernmost site in the

842 Bay of Biscay, La Trinité-sur-Mer, from 2011 to 2013. Values in 2013 labelled as 'missing'

843 indicate that the individual was not found even after two days of searching and presumed dead;

844 value in 2011 labelled 'NA' reflects expansion of census search area in 2012 to include

845 additional individuals due to disappearance of over $75 \%$ of the individuals seen in 2011.

846

\begin{tabular}{|c|c|c|c|}
\hline \multirow[t]{2}{*}{ Known Individuals } & \multicolumn{3}{|c|}{ Aperture Diameter $(\mathrm{mm})$ by Year of Observation } \\
\hline & 2011 & 2012 & 2013 \\
\hline Ind 1 & 8 & 9.5 & 11 \\
\hline Ind 2 & NA & 9.5 & 10 \\
\hline Ind 3 & 8 & 11 & 10 \\
\hline Ind 4 & 8.5 & 10 & missing \\
\hline Ind 5 & 8 & 9.5 & 9 \\
\hline Ind 6 & 9 & 9 & missing \\
\hline Ind 7 & 10 & 8.5 & 8 \\
\hline Ind 8 & 10.5 & 10 & 9 \\
\hline Ind 9 & NA & 10 & 10 \\
\hline Ind 10 & NA & 10 & 9 \\
\hline
\end{tabular}


848 Figure 1 . Measurements of body width $(\mathrm{mm})$ (minus parapodia and chaetae) at the $10^{\text {th }}$ chaetiger

849 versus measurements of tube-cap aperture diameter $(\mathrm{mm})$ in small Diopatra biscayensis. Linear 850 regression relationship: $y=1.202 x+0.0375, \mathrm{R}^{2}=0.79, \mathrm{~N}=17$, aperture sizes 1.5 to $7 \mathrm{~mm}, 10^{\text {th }}$ 851 chaetiger widths 1.34 to $5.08 \mathrm{~mm}$.

852

853 Figure 2 . Mean density per $\mathrm{m}^{2}$ with $95 \%$ confidence limits. The nine sites in the Bay of Biscay 854 are in rows one and two and are arranged from south (Arcachon) to north (La Trinité-sur-Mer), 855 while those of the Normano-Breton Gulf are in row three and are west to east. Note to allow 856 visual comparison the vertical scale of density per meter square is a logarithmic scale and is 857 constant for all sites.

Figure 3. Size frequency distributions of Diopatra biscayensis for 2011, 2012, and 2013.

860 Proportions by aperture diameter are shown for each population as well as number of individuals

861 ('N') in the census. The census size in most cases represents three hours or more of searching.

862 The populations from the Bay of Biscay are arranged from south to north: Arcachon, Verdon863 sur-Mer, Châtelaillon-Plage, Tharon Plage, Le Pouliguen, Baie du Bile, Dolmen du Crapaud, and 864 La Trinité-sur-Mer. Those from the Normano-Breton Gulf are arrayed west to east: Quatre 865 Vaux, Sainte-Anne reef at Cherrueix, and Champeaux. The vertical dotted line separates the 866 likely young of the year $(<5 \mathrm{~mm}$ aperture inner diameter $)$ from presumptive adults. Solid dark 867 bars are from 2011, grey bars from 2012, open bars from 2013. The populations at Saint-Géran 868 and Gatseau were discovered in 2013 so have only one year of data and are not displayed; see 869 Table 1 for size ranges. The 2013 census for the population at Le Dolmen du Crapaud is small 870 due to a mud deposition event that killed the lower intertidal portion of the population. 
872 Figure 4. Locations of survey sites in France, with regional estimates of larval connectivity.

873 Background map: black symbols in Brittany are sites surveyed between La Trinité-sur-Mer and

874 the central English Channel where we did not find Diopatra $(\mathrm{o}=$ appropriate habitat; $\mathrm{x}=$

875 inappropriate habitat); red circles (online color map) or black circles (print map) in the southern

876 Bay of Biscay are Diopatra population sites: $\mathrm{CP}=$ Châtelaillon-Plage, GA=Plage de Gatseau,

877 VD=Verdon-sur-Mer, AR=Arcachon. Upper inset map: Normano-Breton Gulf region:

$878 \mathrm{CH}=$ Champeaux, $\mathrm{SA}=$ Sainte-Anne, $\mathrm{QV}=\mathrm{Quatre}$ Vaux, SG=Saint- Géran, JO=Jospinet. Lower

879 inset map: upper Bay of Biscay in the Vilaine/Loire region: LT=La Trinité-sur-Mer,

880 DC=Dolmen du Crapaud, BB=Baie du Bile, $\mathrm{PG}=$ Le Pouliguen, TP=Tharon Plage. Shading

881 colors (online) or greyscale (print) in inset maps indicate larval connectivity estimates after 6

882 days of dispersal, from Lagrangian particle modeling of releases from the survey sites, using

883 velocity fields from MARS2D models. Color scale or greyscale on right in $\log _{10}$ units; thus, '-1'

884 represents the recruitment zone of $10 \%$ of the larvae while ' -6 ' is the recruitment zone of

$8850.0001 \%$ of the larvae. The rapidity of the change indicates that dispersal is extremely local.

886

887 Figure 5. Larval connectivity as a function of distance from release point, after 6 days of

888 dispersal. Data are from Lagrangian transport simulations with passive particles, using velocity

889 fields from 250 meter scale MARS2D models. Each line represents the decline in connectivity

890 as a function of distance from an individual release location. Releases in the Normano-Breton

891 Gulf were from adult population locations at Champeaux $(\mathrm{CH})$, Sainte-Anne (SA), and Quatre

892 Vaux (QV). Releases in the Vilaine/Loire region within the upper Bay of Biscay were from the

893 Dolmen du Crapaud (DC), the Baie du Bile (BB), Le Pouliguen (PG), and Tharon Plage (TP). 
894 See Fig. 4 for map locations. Average slope of the lines: Normano-Breton Gulf -0.0996, Bay of 895 Biscay Vilaine/Loire -0.1000.

896

897 Figure 6. Mussel culture at Quatre Vaux, Baie de l'Arguenon (QV) within the Normano-Breton

898 Gulf. Bouchots are the vertical pilings which are wrapped with mussel ropes for final grow-out.

899 Chantiers are the racks in the foreground with the horizontal seed ropes draped between them. A

900 second row of chantiers and bouchots is visible in the background, parallel to the row in the

901 foreground. 


\section{D. biscayensis}

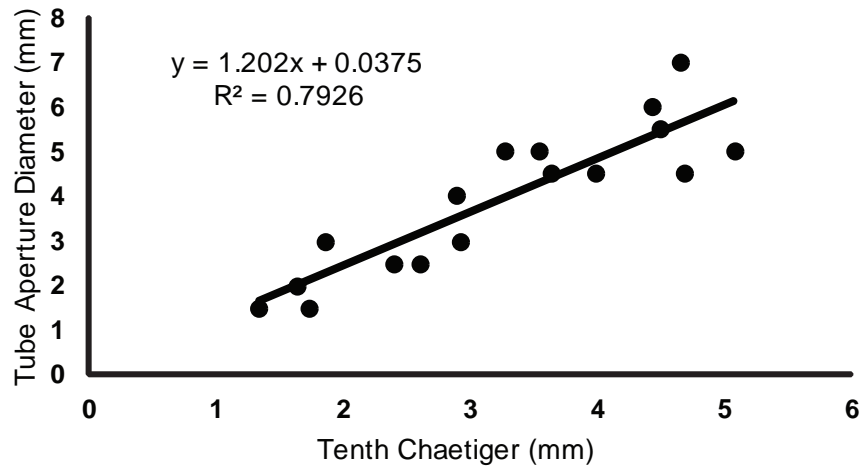




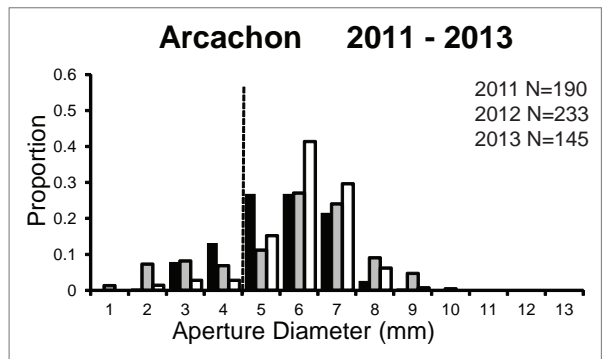

Tharon Plage $2011-2013$

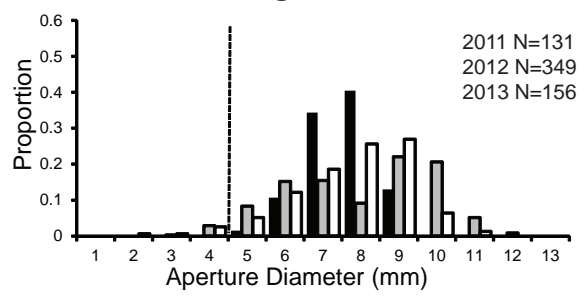

Dolmen du Crapaud 2011 - 2013
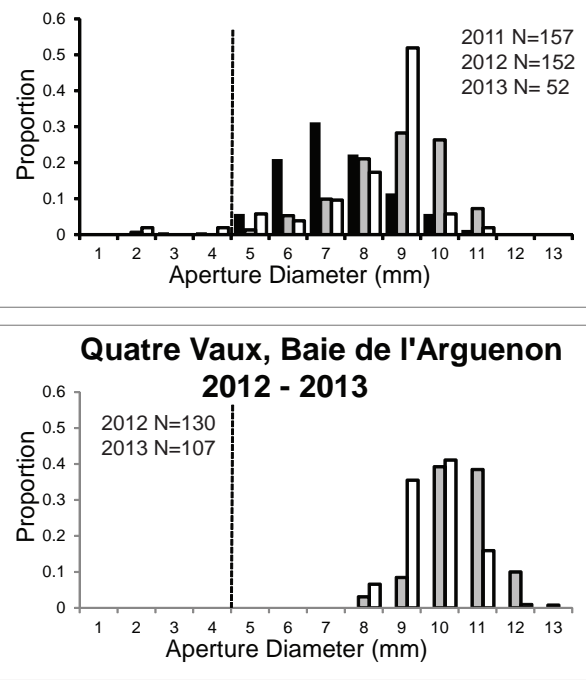

\section{Verdon - sur - Mer 2011 - 2013}

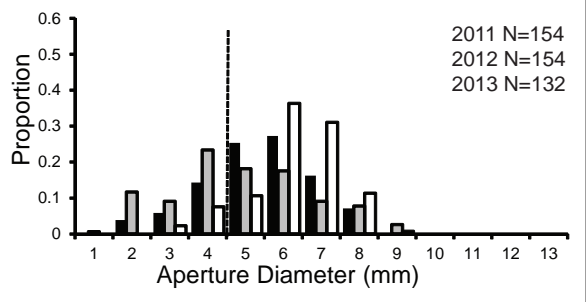

Le Pouliguen 2012 - 2013

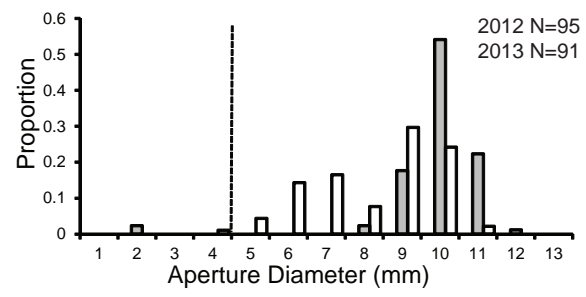

La Trinité - sur - Mer 2011 - 2013
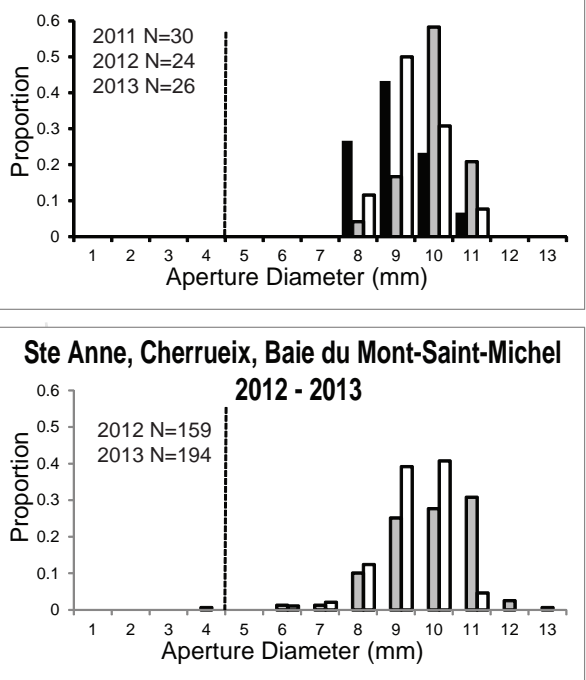

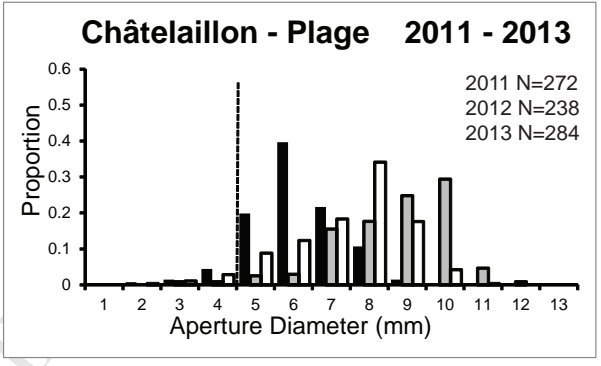

Baie du Bile 2011 - 2013

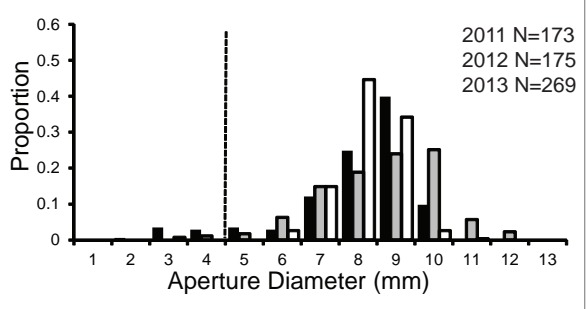

Champeaux, Baie du Mont-Saint-Michel 2011 - 2013

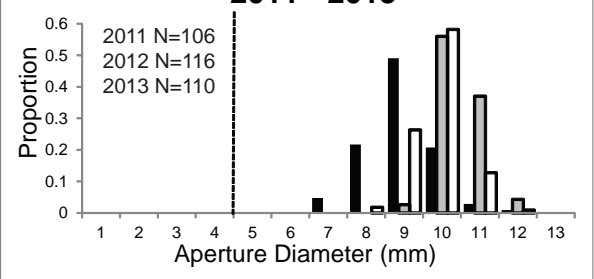




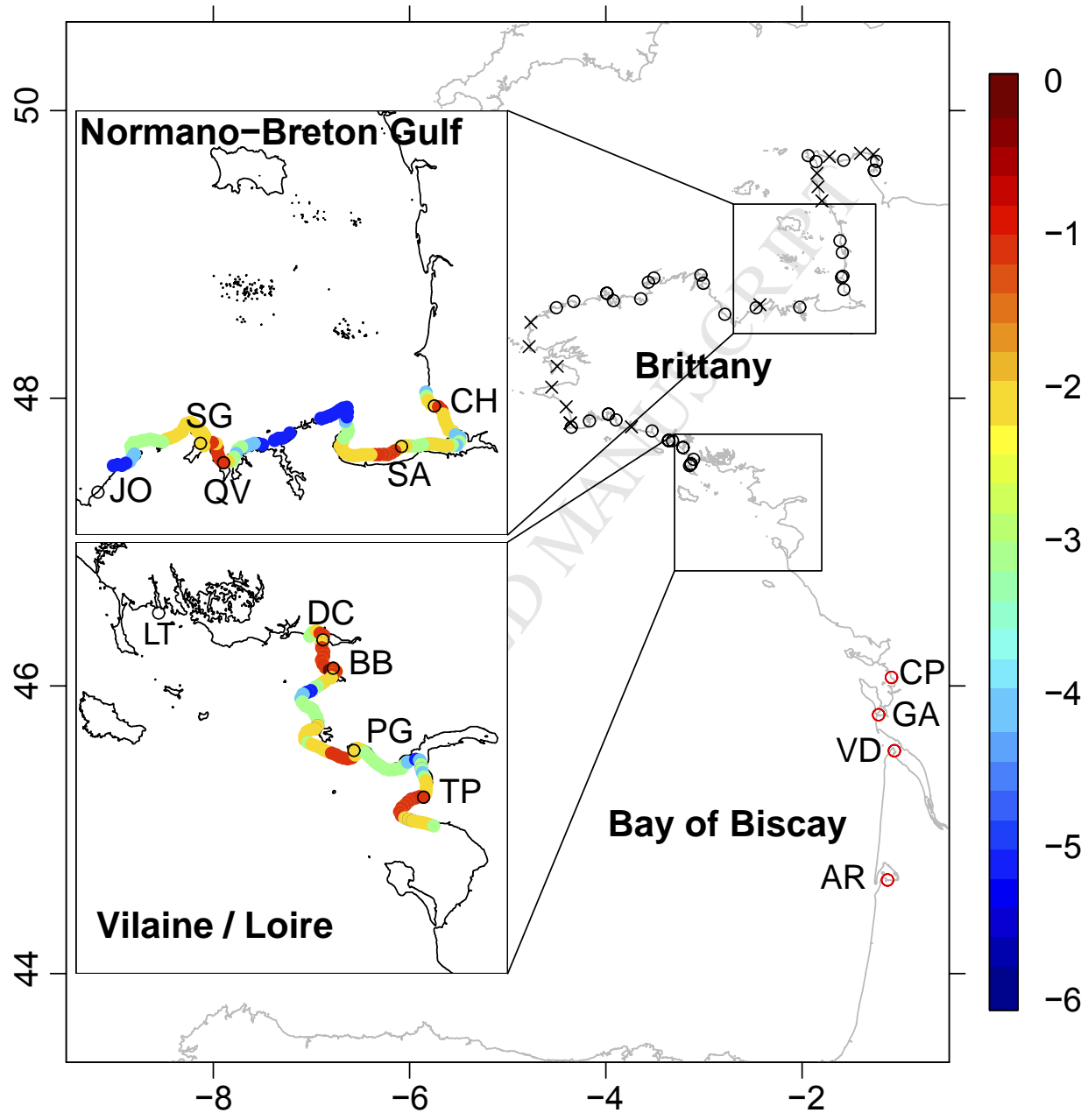




\section{Normano-Breton Gulf}

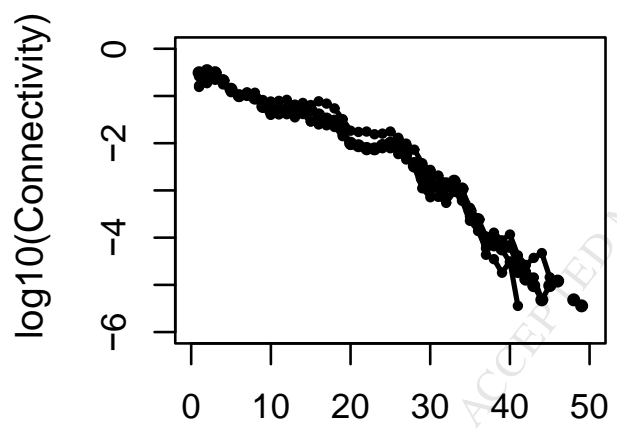

Distance $(\mathrm{km})$

\section{Vilaine / Loire}

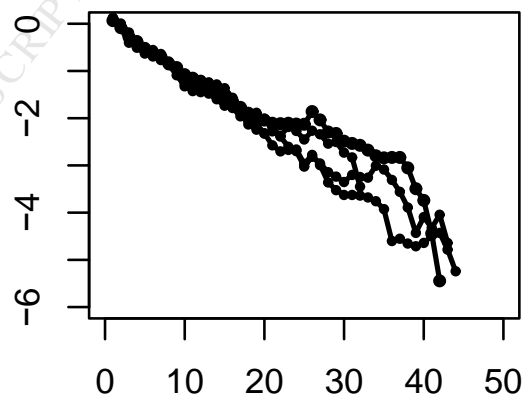

Distance $(\mathrm{km})$ 


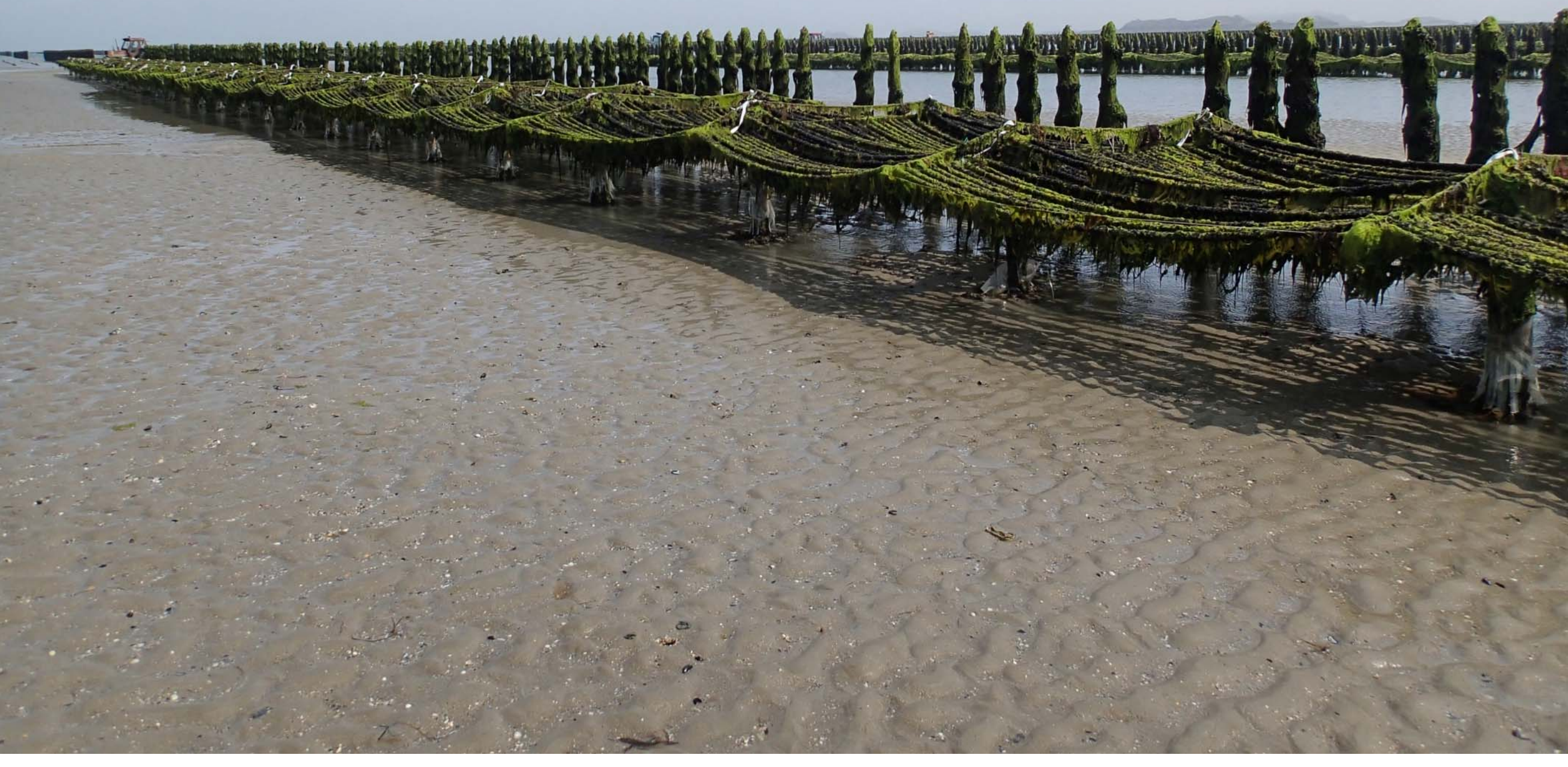

